\title{
Influence of stunning methods on the welfare of glycerine-fed lambs ${ }^{1}$
}

\section{Influência de métodos de atordoamento sobre o bem estar de cordeiros alimentados com glicerina}

\author{
Viviane Correa Santos ${ }^{2 *}$; Jane Maria Bertocco Ezequiel ${ }^{3}$; \\ Elisa Marcela de Oliveira D’Aurea ${ }^{4}$; Vanessa Ruiz Fávaro²; \\ David Attuy Vey da Silva ${ }^{4}$; Antonio Carlos Homem Júnior ${ }^{2}$; \\ Josiane Fonseca Lage²; João Alberto Negrão
}

\begin{abstract}
The effects of electrical and non-penetrating bolt pistol stunning methods were evaluated. Forty uncastrated, mixed-breed ( $1 / 2$ Santa Inês x $1 / 2$ Dorper) males were used. The welfare of lambs was not affected $(\mathrm{P}>0.05)$ by the inclusion of glycerin in the diet. The color of the meat ( 24 hours after slaughter) of lambs stunned with a non-penetrating bolt pistol was lighter ( $\mathrm{P}>0.05)$. The shear force, water-holding capacity, lipid oxidation and sarcomere length were not influenced by diet and stunning methods and exhibited average values of $1.59 \mathrm{kgf} / \mathrm{cm}^{2}, 59.65 \%, 0.62 \mathrm{mg} / \mathrm{kg}$ and $2.26 \mu$, respectively. The animals stunned by electrical stimulation had a higher concentration of total leukocytes $\left(7.22 \times 10^{3} /\right.$ $\mu \mathrm{L})$ and creatine kinase $(81.89 \mathrm{U} / \mathrm{L})$. Based on welfare and meat quality, the non-penetrating bolt pistol can be considered an alternative stunning method for lambs.
\end{abstract}

Key words: Electrical stimulation, sheep, blood parameters, non-penetrating bolt pistol, meat quality

\section{Resumo}

Avaliou-se os efeitos de métodos de atordoamento por estimulação elétrica e pistola de dardo sem penetração. Utilizou-se 40 cordeiros machos não castrados da raça $1 / 2$ Santa Inês x $1 / 2$ Dorper. $O$ desempenho dos cordeiros não foi influenciado $(\mathrm{P}>0,05)$ pela inclusão de glicerina. A cor da carne dos cordeiros (24 h após o abate) atordoados com pistola de dardo sem penetração foi mais clara $(P>0,05)$. A força de cisalhamento, capacidade de retenção de água, oxidação lipídica e comprimento de sarcômero não foram influenciadas pelas dietas e métodos de atordoamento, com médias de $1,59 \mathrm{kgf} / \mathrm{cm}^{2}, 59,65 \%$, $0,62 \mathrm{mg} / \mathrm{kg}$ e $2,26 \mu$, respectivamente. Os animais atordoados por estimulação elétrica apresentaram maior concentração de leucócitos totais $\left(7,22 \times 10^{3} / \mu \mathrm{L}\right)$ e de creatina kinase $(81,89 \mathrm{U} / \mathrm{L})$. A pistola de dardo sem penetração pode ser considerada um método alternativo para o atordoamento de cordeiros visando o bem estar e a qualidade da carne.

Palavras-chave: Estimulação elétrica, ovinos, parâmetros sanguíneos, pistola de dardo sem penetração, qualidade da carne

\footnotetext{
${ }^{1}$ Parte do Projeto de Pós-Doutorado financiado pela Fundação de Amparo à Pesquisa do Estado de São Paulo, FAPESP.

${ }^{2}$ Drs. em Zootecnia, Universidade Estadual Paulista "Julio de Mesquita Filho", UNESP/FCAV, Jaboticabal, SP, Brasil. E-mail: vivianecorreasantos@gmail.com, achomemj@bol.com.br, vanessa_favaro@yahoo.com.br,josilage@gmail.com

${ }^{3}$ Prof $^{\mathrm{a}}$ do Dept ${ }^{\mathrm{o}}$ de Zootecnia, UNESP/FCAV, Jaboticabal, SP, Brasil. E-mail: janembe_fcav@yahoo.com.br

${ }^{4}$ M.e em Zootecnia, UNESP/FCAV, Jaboticabal, SP, Brasil. E-mail: davidattuy@hotmail.com

${ }^{5}$ Prof. do Dept ${ }^{\circ}$ de Ciências Básicas, Universidade de São Paulo, USP/FZEA, Pirassununga, SP, Brasil. E-mail: jnegrao@usp.br

* Author for correspondence
} 


\section{Introduction}

There is growing public concern about the welfare of farm animals. This concern is most often expressed in Europe, where annually there are new rules and laws that address the pre-slaughter management, transport, stunning and slaughter of animals for consumption. Although this concern is less pronounced in Brazil, the methods and strategies of the production and slaughter of animals in Brazil have been influenced by the opinions of European consumers and the laws of the European Union as a result of Brazil's interest in exporting meat to European countries.

Studies show a close relationship between the welfare of farm animals and the final quality of the meat produced, which results primarily from the effect of stress on the body of the individual animal. Because animals are incorrectly managed during stunning, a series of stress responses occur in the animals that may alter the quality of meat (FOURY et al., 2005).

Numerous European studies relate the quality of the meat with animal welfare during stunning (VERGARA; GALLEGO, 2000; CHANNON; PAYNE; WARNER, 2003; HAMBRECHT et al., 2004; ÖNENÇ; KAYA, 2004). The activity of the main nerve axis (sympathetic-medullary and cortical-adrenal) increases as a result of the stress generated during stunning with a consequent release of catecholamines and cortisol, which causes a general increase in the organism's energy and metabolic expenditure. In the muscles, these changes are reflected in varying $\mathrm{pH}$ levels, which distort the spatial conformation of proteins and the modification of physico-chemical $(\mathrm{pH}$, waterholding capacity), sanitary (lipid oxidation) and sensory (color, tenderness/texture) meat quality parameters (HAMBRECHT et al., 2004).

In addition to the interest in animal welfare, there is an increasing global concern regarding the environment, global warming, sustainable development and the possible exhaustion of fossil fuel reserves, which has motivated several studies on biodiesel. Biodiesel is manufactured using a chemical process known as transesterification, whereby glycerin is separated from fat or vegetable oil.

Animal feed has been noted as a possible use for the crude glycerin generated as a byproduct of biodiesel production. The use of crude glycerin in animal feed has been the subject of previous studies, particularly in Europe. However, the recent surge in biodiesel production and the availability of large quantities of crude glycerin has generated renewed interest in glycerin's use in animal feed.

To date, there is limited information on the inclusion of glycerin in the diets of sheep in Brazil, although this information is necessary to the design of more efficient diets. Glycerin's particular characteristics must be understood and characterized if glycerin is to be used as feed for sheep. Moreover, alternative stunning methods are necessary not only to ensure the welfare of the animals but also the appropriate physico-chemical, hygienic-sanitary and sensorial qualities of meat. Thus, this study aimed to evaluate the influence of stunning methods on the welfare and meat quality of lambs fed with glycerin.

\section{Material and Methods}

\section{Location, diet and pre-experiment management}

The experiment was performed at the Animal Unit of Digestive and Metabolic Studies (Unidade Animal de Estudos Digestivos e Metabólicos) of the Department of Animal Science (Departamento de Zootecnia), the School of Agriculture and Veterinary Sciences (Faculdade de Ciências Agrárias e Veterinárias) of the Jaboticabal Campus of the Julio de Mesquita Filho São Paulo State University (Universidade Estadual Paulista Júlio de Mesquita Filho), the State of São Paulo.

During the pre-experiment period, the lambs were individually identified using a collar, wormed and supplemented with vitamins $\mathrm{A}, \mathrm{D}, \mathrm{E}, \mathrm{B}_{12}$ and iron. 
Two diets were formulated with a forage:concentrate ratio of 20:80. Ground tifton hay was used as forage. The diets were identified as follows: G0 - control without glycerin and G10 - $10 \%$ glycerin as part of the concentrate (Table 1). The glycerin was obtained from soybean oil and comprised $83 \%$ glycerol, $11 \%$ water, $6 \%$ salt (of which 99\% was $\mathrm{NaCl}$ ) and $0.01 \%$ methanol (Caramuru Feeds, Ltd. (Caramuru Alimentos Ltda.)).

Table 1. Percentage of ingredients and chemical composition of experimental diets (\% DM).

\begin{tabular}{lcc}
\hline \multirow{2}{*}{\multicolumn{1}{c}{ Ingredients }} & \multicolumn{2}{c}{ Diets } \\
\cline { 2 - 3 } & $\mathbf{G 0}^{\mathbf{1}}$ & $\mathbf{G 1 0}^{\mathbf{2}}$ \\
\hline Tifton hay & 20.00 & 20.00 \\
Corn grain & 55.40 & 45.40 \\
Glycerin & - & 10.00 \\
Soybean meal & 23.00 & 23.00 \\
Limestone & 0.60 & 0.60 \\
Mineral mixture* & 1.00 & 1.00 \\
\hline Total & 100.00 & 100.00 \\
\hline & Composition $\mathbf{( \% ~ D M ) ~}$ \\
\hline Dry matter & 89.59 & 87.81 \\
Mineral matter & 5.05 & 5.27 \\
Organic matter & 84.54 & 82.54 \\
Ether extract & 3.19 & 3.15 \\
Crude protein & 20.70 & 20.00 \\
Metabolizable energy & 3.00 & 3.00 \\
(Mcal/kg DM)** $^{*}$ & & \\
\hline
\end{tabular}

${ }^{\mathrm{I}} \mathrm{G} 0$ : control without glycerin; ${ }^{2} \mathrm{G} 10$ : formulated with $10 \%$ glycerin.

*Mixing comercial mineral for sheep $(\mathrm{P}=60 \mathrm{~g} ; \mathrm{Ca}=110 \mathrm{~g}$; $\mathrm{Na}=195 \mathrm{~g} ; \quad \mathrm{Cl}=300 \mathrm{~g} ; \quad \mathrm{Mg}=10 \mathrm{~g} ; \quad \mathrm{S}=25 \mathrm{mg} ; \quad \mathrm{Zn}=4.000 \mathrm{mg} ;$ $\mathrm{Cu}=600 \mathrm{mg} ; \mathrm{Mn}=600 \mathrm{mg} ; \mathrm{Fe}=1.200 \mathrm{mg} ; \mathrm{Co}=100 \mathrm{mg} ; \mathrm{I}=180 \mathrm{mg}$; $\mathrm{Se}=12 \mathrm{mg} ; \mathrm{Fl}$ (máximo) $=0,60 \mathrm{mg})$

$* * \mathrm{EM}=12.71-0.0108(\mathrm{ADF})+0.0262(\mathrm{EE})$.

** De Boever, Cottyn and Debradanger (1999), values obtained in $\mathrm{MJ} / \mathrm{kg} \mathrm{DM}$ and processed Mcal $/ \mathrm{kg} \mathrm{DM}$.

Source: Elaboration of the authors.

\section{Performance}

A total of 40 uncastrated mixed breed ( $1 / 2$ Santa Inês $x 1 / 2$ Dorper) males weaned at an average age of 90 days and an average weight of $21 \pm 2.3 \mathrm{~kg}$ were used. The animals were identified and divided into two blocks, each with 20 replicates.

The lambs were fed twice daily ( 8 to 16 hours) with the prepared diets and had access to water ad libidum throughout the experimental period. The supplied quantities of feed were weighed daily and adjusted according to the intake, whereby a $5 \%$ surplus was allowed. The intake was determined by discounting the daily leftovers from the total diet provided. The dry matter (DM) intake, the confinement duration, the average daily gain and the feed conversion were evaluated. To control development, the lambs were weighed every 14 days and then weekly after the first animals were slaughtered.

\section{Stunning and slaughter}

Upon reaching approximately $33 \mathrm{~kg}$, the animals were weighed and restricted for 16 hours to a fluid diet. Half of the animals were stunned by electrical stimulation with $330 \mathrm{~V}$ for 8 seconds (electrodes applied to both sides of the head behind the ears), and the other half were stunned with a non-penetrating bolt pistol, which was approved by the ethics committee of the researchers' university department. Bleeding was performed by cutting the jugular veins and carotid arteries immediately after stunning.

\section{Qualitative analyses of meat}

After skinning, evisceration and the removal of the extremities (hooves) and head, the carcass $\mathrm{pH}$ measurements were obtained approximately 45 minutes after slaughter using a digital $\mathrm{pH}$ meter (Texto, model 205). The electrode was inserted directly in the Longissimus lumborum muscle, and two measurements were obtained on the right side of the carcass. The carcasses were then transferred to a refrigeration chamber (at a temperature of approximately $2{ }^{\circ} \mathrm{C}$ ), where the carcasses remained for $24 \mathrm{~h}$, after which the $\mathrm{pH}$ was again measured 24 $\mathrm{h}$ after slaughter. 
To evaluate the color, a Minolta Chroma Meter colorimeter CR-400 and the International Committee on Illumination (CIE) 1976 L*, a* and $b^{*}$ system (CIELAB) were used. The calibration was performed using a standard white tile. The color was determined at 45 minutes and $24 \mathrm{~h}$ after slaughter in the Longissimus lumborum after cutting the muscle to expose the myoglobin to oxygen, following Cañeque and Sañudo (2005).

The carcasses were then halved longitudinally, and the left side was divided into five anatomical sections: neck, shoulder, rib, loin and leg. The cuts were dissected using scalpel and knife until the Longissimus lumborum muscle was reached. Samples were obtained from the medial portion of the muscle to determine the water-holding capacity (WHC), shear force, lipid oxidation and sarcomere length.

The method described by Hamm and cited by Cañeque and Sañudo (2005) was used to determine the WHC. Meat samples of $400 \mathrm{mg}$ were placed on filter paper in the transverse direction of the fibers between two acrylic plates, and a $10 \mathrm{~kg}$ weight was placed on top for 5 minutes. Subsequently, the samples were weighed, and the quantity of water lost was calculated by subtraction. The result was expressed as the percentage of water exuded relative to the sample's initial weight.

To determine the shear force, the samples were baked in an industrial oven preheated to $165^{\circ} \mathrm{C}$, until the internal temperature of the samples reached 70 ${ }^{\circ} \mathrm{C}$. Then, the samples were removed from the oven and cooled at room temperature for 30 minutes. Next, the samples were cut into $1 \mathrm{~cm}^{2}$ cubes, avoiding connective tissue and fat, and cut in the transverse direction of the muscle fibers by a texture analyzer apparatus coupled to a Warner-Bratzler device with the values expressed in $\mathrm{kgf} / \mathrm{cm}^{2}$.

The analysis of 2-thiobarbituric acid reactive substances (TBARS) or lipid oxidation (expressed in $\mathrm{MG}$ of malondialdehyde/kg of sample) was performed by weighing $5 \mathrm{~g}$ of homogenized sample and adding $25 \mathrm{ml}$ of $7.5 \%$ TCA (trichloroacetic acid). Next, $4 \mathrm{ml}$ of the filtrate was homogenized in a test tube with $1 \mathrm{ml}$ of TCA and $5 \mathrm{ml}$ of TBA (thiobarbituric acid). The tubes were placed in boiling water for 40 minutes. After cooling, readings were obtained in a spectrophotometer at $538 \mathrm{~nm}$ and evaluated relative to a standard curve, according to the method described by Pikul, Leszczynski and Kummerow (1989).

The sarcomere length was determined by laser diffraction (CROSS; WEST; DUTSON, 1981) of muscle fibers obtained from sliced cubes measuring $1 \mathrm{~cm}$ in duplicate from different parts of the Longissimus lumborum.

\section{Analysis of blood parameters}

Blood samples were collected in $5 \mathrm{ml}$ Vacuotainer ${ }^{\circledR}$ tubes at the time of bleeding immediately after cutting the blood vessel. The glucose concentration, the erythrocyte and total leukocyte counts and the determination of hematocrit were performed on the same day as slaughter because of the blood sample collection protocol, thereby avoiding changes in the stability of the measured parameters.

The concentrations of lactate, creatine kinase and glucose, the total leukocyte and erythrocyte counts and the determination of hematocrit were performed using commercial kits, and the cortisol concentration was determined using a Monobind cortisol enzyme immunoassay (EIA) kit on an enzyme-linked immunosorbent assay (ELISA) apparatus (Multiscan MS, Labsystem ${ }^{\circledR}$ ).

\section{Statistical analysis}

The statistical design used to evaluate the performance was a randomized block with two diets and 20 replicates. The qualitative traits of meat and blood parameters were evaluated using a randomized block with a 2 x 2 factorial design (two diets and two stunning methods) with 10 replicates. The results were submitted to analysis of variance and means compared with a Tukey's test 
at $5 \%$ probability. The data were analyzed using the statistical analysis system (SAS, 2001).

\section{Results and Discussion}

Feedlot-finished lambs fed with 10\% glycerol performed similarly to lambs in the control group because the confinement time did not differ between groups, lasting on average 48.89 days. Gomes et al. (2011) evaluated the influence of diets supplemented with 0,15 and $30 \%$ glycerin as a substitute for corn on the performance of Santa Inês lambs with the same confinement period as in the present study (Table 2).

Table 2. Initial and final weight, duration of confinement (DC), average daily gain (ADG), dry matter intake (DMI) and feed conversion (FC) of lambs fed with/without glycerin.

\begin{tabular}{lcccc}
\hline \multirow{2}{*}{ Variable } & \multicolumn{3}{c}{ Diets } \\
\cline { 2 - 4 } & $\mathbf{G 0}^{\mathbf{1}}$ & $\mathbf{G 1 0}^{\mathbf{2}}$ & $\mathbf{C V ~ ( \% )}$ & $\mathbf{P}$ \\
\hline Initial weight & 20.95 & 20.79 & 8.11 & 0.7773 \\
Final weight & 33.96 & 33.47 & 3.32 & 0.1809 \\
DC (days) & 46.45 & 51,30 & 19.05 & 0.1079 \\
ADG (kg/animal/day) & 0.305 & 0.278 & 21.66 & 0.1866 \\
DMI (kg/day) & 1.341 & 1.325 & 10.77 & 0.7201 \\
FC (kg DM/ kg gain) & 4.52 & 4.89 & 15.03 & 0.1128 \\
\hline
\end{tabular}

Medium lines do not differ by Tukey test $(\mathrm{p}>0.05)$

${ }^{1} \mathrm{G} 0$ : control without glycerin; ${ }^{2} \mathrm{G} 10$ : formulated with $10 \%$ glycerin.

$\mathrm{CV}=$ coefficient of variation

$\mathrm{P}=$ probability

Source: Elaboration of the authors.

The DM intake was not affected $(\mathrm{P}>0.05)$ by the diets. This variable is an important factor in the performance of feedlot-finished sheep because the factor is considered to determine the supply of nutrients necessary to meet the maintenance and weight gain requirements of the animals (SNIFFEN et al., 1993). and Schröder and Südekum (2007) indicated that glycerin with different degrees of purity could be included as up to $10 \%$ of the DM in the diet of ruminants without negatively affecting the food intake and the digestibility of the diet components. Similar results were found in the present study with respect to DM intake.

The average DM intake during the experiment was $1.333 \mathrm{~kg} /$ day, which is in the range recommended by the National Research Council (NRC) (2007) for sheep in this category (1.0 to 1.3 $\mathrm{kg} /$ day). Lage et al. (2010) evaluated the effects of glycerin levels $(0,3,6,9$ and 12\%) in the finishing diet of Santa Inês lambs and observed lower DM intake values $(1,120.71,1,115.54,898.84,942.07$ and $782.76 \mathrm{~g} /$ day, respectively) than the present study. This finding is most likely the result of the higher methanol content found in the crude glycerin used by those authors $(8.66 \%)$ than in the present study $(<1.0 \%)$. However, the high health risk associated with the consumption of methanol that results from the inclusion of crude glycerin in the diet is not expected in ruminant animals because methanol is naturally produced in the rumen as a result of pectin fermentation, as shown by Pol and Demeyer (1988). Pol and Demeyer continuously infused a methanol solution (1 mol L-1) at a rate of $19 \mathrm{~mL} \mathrm{~h}-1$ in the rumen of sheep and found that the methanol was converted to methane in the rumen of animals.

The average DM intake found in the present study was higher than that reported by Gomes et 
al. (2011) in feedlot-finished Santa Inês lambs, with an intake on average of 1.26, 1.30 and 1.27 $\mathrm{kg}$ animal day at 0,15 and 30\% glycerin in diets, respectively, and higher than that reported by Gunn et al. (2010a) in feedlot-finished lambs and sheep, which showed an average daily intake of 1.130 and $1.190 \mathrm{~kg} /$ day, with 0 and $15 \%$ of glycerin, respectively.

Although obtained for bovine animals on diets that included high levels of grain, the results exhibited no influence on DM intake of the administration of glycerol up to $16 \%$ of the total diet (DEFRAIN; HIPPEN; KALSCHEUR, 2004; CHUNG; RICO; MARTINEZ, 2007; MACH; BACH; VELARDE, 2008). However, in studies of feedlot-finished cattle Schröder and Südekum (2007), Pyatt, Doane and Cecava (2007) and Parsons, Shelor and Drouillard (2009) found a reduction in DM intake when glycerin levels were greater than 10. Additionally, the reduction in the acetate:propionate ratio may explain the decreased intake observed by Abo el-nor, Abughazaleha and Potua (2010). Moreover, this study suggests that diet did not influence the intake parameters or carcass characteristics but that these factors may be affected by differences in the diet ingredients and the glycerin purity, which may explain this divergence of results.

The average daily weight gain and feed conversion did not differ between diets. The average weight gain obtained with both diets was 292 g/day. The NRC (2007) suggests a daily weight gain between 200 and $250 \mathrm{~g}$ for lambs up to four months old with $30 \mathrm{~kg}$ of body weight, and the gains observed in the present experiment were above this range. Gomes et al. (2011) found average daily gains of 210, 240 and $230 \mathrm{~g}$ in Santa Inês lambs fed with glycerin inclusion levels of 0,15 and $30 \%$, respectively, and slaughtered at $35 \mathrm{~kg}$.

The feed conversion, which is based on the DM intake required to produce one $\mathrm{kg}$ of body weight, was on average 4.71. This value was larger than the values reported by Gomes et al. (2011), who obtained mean values of $6.39,5.73$ and 5.92 in Santa Inês lambs fed with glycerin at glycerin inclusion levels of 0,15 and $30 \%$, respectively. The feed conversion can be influenced by several factors, such as the energy diversity and the quality of the fiber in the diet, age, sex and gain differences according to genetic group, which makes it difficult to compare these values between different studies (RESTLE et al., 2001).

Table 3 shows that there was no effect $(\mathrm{P}>$ 0.05 ) of the interaction diet $\mathrm{x}$ stunning method. Diet and stunning method did not influence the $\mathrm{pH}$ at 45 minutes and 24 hours after slaughter. The decline in average $\mathrm{pH}$ from 6.43 to 5.75 at 24 hours after slaughter indicates the process of rigor mortis (SILVA SOBRINHO; PURCHAS; KADIM, 2005). 
Table 3. $\mathrm{pH}$ and color muscle Longissimus lomborum lamb feedlot.

\begin{tabular}{|c|c|c|c|c|c|c|c|c|}
\hline \multirow[t]{2}{*}{ Parameter } & \multirow{2}{*}{$\begin{array}{c}\mathrm{pH} \\
45 \mathrm{~m} \\
\end{array}$} & \multirow{2}{*}{$\begin{array}{l}\mathrm{pH} \\
24 \mathrm{~h} \\
\end{array}$} & \multicolumn{3}{|c|}{$\begin{array}{c}\text { Color } \\
45 \mathrm{~m}\end{array}$} & \multicolumn{3}{|c|}{$\begin{array}{c}\text { Color } \\
24 \mathrm{~h}\end{array}$} \\
\hline & & & $\mathbf{L}^{*}$ & $a^{*}$ & $\mathbf{b}^{*}$ & $\mathbf{L}^{*}$ & $a^{*}$ & $\mathbf{b}^{*}$ \\
\hline \multicolumn{9}{|l|}{ Diet } \\
\hline G0 & 6.44 & 5.74 & $33.57 \mathrm{a}$ & 17.77 & 4.31 & 36.82 & 17,54 & 7,98 \\
\hline G10 & 6.41 & 5.75 & $32.00 \mathrm{~b}$ & 17.85 & 4.23 & 36.39 & 17,97 & 7,85 \\
\hline \multicolumn{9}{|l|}{ Method } \\
\hline Pistol & 6.46 & 5.77 & 33.43 & 17.77 & 4.43 & $38.38 \mathrm{a}$ & 17,33 & 8,32 \\
\hline Electric stimulation & 6.38 & 5.72 & 32.14 & 17.86 & 4.11 & $34.83 b$ & 18,17 & 7,51 \\
\hline Source of variation & \multicolumn{8}{|c|}{$\mathbf{P}$} \\
\hline Diet & 0.64 & 0.83 & 0.03 & 0.90 & 0.70 & 0.76 & 0,58 & 0,91 \\
\hline Method & 0.22 & 0.21 & 0.07 & 0.89 & 0.15 & 0.02 & 0,27 & 0,48 \\
\hline Diet x Method & 0.30 & 0.29 & 0.45 & 0.69 & 0.13 & 0.81 & 0,20 & 0,01 \\
\hline CV (\%) & 3.31 & 2.22 & 6.59 & 11.66 & 16.27 & 12,26 & 13,44 & 45,66 \\
\hline
\end{tabular}

Means followed by different letters in the column, differ by Tukey testa $\mathrm{t} 5 \%$ probability

G0: control without glycerin; G10: formulated with $10 \%$ glycerin

45 minutes after slaughter; 24 hours after slaughter

$\mathrm{L}^{*}=$ lightness; $\mathrm{a} *=$ redness; $\mathrm{b}^{*}=$ yellow color intensity

$\mathrm{CV}=$ coefficient of variation

Source: Elaboration of the authors.

These $\mathrm{pH}$ values are within the range considered normal for sheep meat, which according Cañeque and Sañudo (2005) and Silva Sobrinho, Purchas and Kadim (2005) ranges from 6.56 to 6.69 to 5.56 to 5.78 after 24 hours, and indicate the absence of preslaughter stress. The meat was neither DFD (dark, firm and dry) nor PSE (pale, soft and exudative), and the finding of a normal decline in $\mathrm{pH}$ suggests that other indicators of meat quality, such as WHC and tenderness, will present good results because these indicators are influenced by $\mathrm{pH}$. The results of the present study corroborate Önenç and Kaya (2004), who evaluated the effects of electrical and non-penetrating bolt pistol stunning on the quality of cattle meat and found no differences in $\mathrm{pH}$.

Vergara et al. (2005), who assessed the effect of pre-slaughter handling (stunning with $\mathrm{CO}_{2}$ gas, electric stunning and without stunning) on meat quality in suckling Manchega lambs, found an initial $\mathrm{pH}$ (45 minutes after slaughter) of 6.16 and a final $\mathrm{pH}$ (24 hours after slaughter) of 5.63 for the Longissimus dorsi, which are values close to those found in the present study.

Initial $\mathrm{pH}$ values of 6.36 (45 minutes after slaughter) and 5.49 for final $\mathrm{pH}$ (24 hours after slaughter) in the Longissimus dorsi of Manchega lambs slaughtered at $25 \mathrm{~kg}$ body weight were found in the literature (LINARES et al., 2007b) for electrically stunned animals, and the values were lower than those of the present study.

Electrical stunning methods cause a rapid drop in $\mathrm{pH}$ as a result of the passage of the electrical current through the carcass and increased muscular activity, which results in an acceleration of postmortem glycolysis (TROEGER; WOLTERSDORF, 1990). Therefore, $\mathrm{pH}$ decline appears to be affected by the type of stunning (VERGARA et al., 2005), although other studies did not find differences between the stunning systems (CHANNON; PAYNE; WARNER, 2003). A pH value of 5.9 at 24 hours in the Longissimus dorsi muscle of Santa Inês lambs was found by (VIEIRA et al., 2010) for the same category of animal used in this study and for the same genetic composition and muscle. 
No interaction effect was observed between diet and stunning method for the variables studied (Table 3). Color is the index of freshness and meat quality that most influences the choice of the consumer. According to Miltenburg et al. (1992), the higher the values of $\mathrm{L}^{*}$ are, the paler the meat, and the higher the values of $a^{*}$ and $b^{*}$ are, the more red and yellow appears, respectively. For sheep, ranges are mentioned of 30.03 to 49.47 for L*, 8.24 to 23.53 for $\mathrm{a}^{*}$ and 3.38 to 11.10 for $\mathrm{b}^{*}$ (SAÑUDO et al., 2000). The values obtained in the present study are considered normal for the color of lamb meat.

It was observed that the color of the meat (45 minutes after slaughter) of lambs that were not fed glycerol was lighter as a result of a higher L* value (33.57) compared to lambs fed with glycerin (32.00). No studies were found in the literature that explain the influence of glycerin on meat color.

It was observed that the color of meat (24 hours after slaughter) from lambs stunned with a nonpenetrating bolt pistol was paler as a result of a higher L* value (38.38) compared with electrically stunned lambs (34.83). This lower $L^{*}$ value for electrically stunned animals can be attributed to the lower level of muscle hemoglobin, which results from a lower efficiency of bleeding observed after stunning. The stunning of the animal by any method produces increased blood pressure in the arterial, venous and capillary networks that produces a transient heart rate increase (THORNTON, 1969), which are factors that promote bleeding.

Linares et al. (2007b) found paler meat $\left(\mathrm{L}^{*}=\right.$ 41.3) than the present study in electrically stunned sheep, which could be attributed to a difference in slaughter age and weight $(25 \mathrm{~kg}$ and 70 days, respectively). Additionally, these authors mentioned that $\mathrm{L}^{*}$ values are often higher when lambs are slaughtered at a younger age $(25 \mathrm{~kg})$ because the lambs have more water and less fat compared with older animals. Age modifies the meat's chemical composition and generates increased fat deposition and decreased water quantities in the muscle tissue, which results in meat with less elevated $\mathrm{L}^{*}$ values, i.e., darker.

The redness intensity results (45 minutes and 24 hours after slaughter) did not differ between diets and methods, with an average value of 17.75. A similar result was described by Linares et al. (2007b) for the redness intensity in the Longissimus dorsi muscle of electrically stunned lambs (Table 3).

There was no effect $(\mathrm{P}>0.05)$ of the diet $\mathrm{x}$ stunning method interaction on the shear force, WHC, lipid oxidation and sarcomere length (Table 4). The shear force, WHC, lipid oxidation and sarcomere length were not influenced by diet and stunning methods with mean values of $1.59 \mathrm{kgf} /$ $\mathrm{cm}^{2}, 59.65 \%, 0.62 \mathrm{mg} / \mathrm{kg}$ and $2.26 \mu$, respectively. Vergara et al. (2005) observed higher shear force values, i.e., harder, for meat from electrically stunned lambs, with an average of $4.09 \mathrm{kgf} / \mathrm{cm}^{2}$. Additionally, Miranda-la Lama et al. (2009) and Ekiz et al. (2012) found higher shear force values (6.14 and $4.28 \mathrm{kgf} / \mathrm{cm}^{2}$, respectively), when these researchers studied the effect of pre-slaughter handling on the quality of lamb meat. 
Table 4. Quality characteristics of muscle Longissimus lumborum lamb feedlot.

\begin{tabular}{lcccc}
\hline \multicolumn{1}{c}{ Parameter } & $\begin{array}{c}\text { FC } \\
\mathbf{k g f} / \mathbf{c m}^{2}\end{array}$ & $\begin{array}{c}\text { CRA } \\
\mathbf{\%}\end{array}$ & $\begin{array}{c}\text { TBARS } \\
\mathbf{m g} / \mathbf{k g}\end{array}$ & $\begin{array}{c}\text { CS } \\
\boldsymbol{\mu}\end{array}$ \\
\hline Diet & & & & \\
G0 & 1.58 & 58.69 & 0.50 & 2.28 \\
G10 & 1.59 & 60.61 & 0.73 & 2.24 \\
\hline Method & & & & \\
Pistol & 1.60 & 60.23 & 0.59 & 2.29 \\
Electric stimulation & 1.57 & 59.07 & 0.64 & 2.23 \\
\hline \multicolumn{2}{c}{ Source of variation } & & P-values & \\
\hline Diet & 0.94 & 0.39 & 0.05 & 0.67 \\
Method & 0.78 & 0.60 & 0.70 & 0.50 \\
Diet x Method & 0.61 & 0.47 & 0.44 & 0.42 \\
\hline CV (\%) & 22.20 & 11.60 & 60.06 & 11.28 \\
\hline
\end{tabular}

Means in columns do not differ by Tukey testa $\mathrm{t} 5 \%$ probability

G0: control without glycerin; G10: formulated with 10\% glycerin

$\mathrm{SF}=$ shear force; WRC $=$ water retention capacity; TBARS $=$ numbers of reative substances to thiobarbituric acid-2; $\mathrm{SL}=$ sarcomere lenght

$\mathrm{CV}=$ coefficient of variation

Source: Elaboration of the authors.

Based on the results for shear force, the flesh of lambs can be described as soft because according to Cezar and Souza (2007), ovine meat with shear strength values below $2.27 \mathrm{kgf} / \mathrm{cm}^{2}, 2.28$ to 3.63 $\mathrm{kgf} / \mathrm{cm}^{2}, 3.64$ to $5.44 \mathrm{kgf} / \mathrm{cm}^{2}$ and above $5.44 \mathrm{kgf} /$ $\mathrm{cm}^{2}$ can be classified as soft, medium soft, tough and extremely tough, respectively.

A significant portion of the WHC results from the integrity of the myofibrillar and sarcoplasmic proteins, which when denatured by a sharp decrease in $\mathrm{pH}$ associated with an inappropriate cooling system can reduce the WHC. However, the diets did not influence $(\mathrm{P}>0.05)$ the ability to retain water. The effect of adding glycerol to the diet on muscle water retention capacity was confirmed by Parker, Dobson and Fitzpatrick (2007), who worked with beef cattle fed only with glycerol during transport and found that the treatment with glycerol caused hyperhydration in the animals, which subsequently resulted in improved meat quality. This outcome enables us to infer that the meat of animals fed with higher levels of crude glycerin in the diet may have lower muscle exudate losses as a result of glycerol's ability to retain water in the muscle.

Silva Sobrinho, Purchas and Kadim (2005) studied the quality of meat from lambs slaughtered at 300 days and found shorter sarcomere lengths with an average value of $1.66 \mu \mathrm{m}$. This lesser tenderness has been attributed to the direct effects of $\mathrm{pH}$ on the activity of proteolytic enzymes that degrade the myofibrillar muscle structure. However, nonenzymatic causes have also been suggested. Shorter sarcomere lengths are recognized as a cause of meat toughness, and it appears that these lengths increase when the final $\mathrm{pH}$ decreases below 6.2 (PURCHAS; AUNGSUPAKORN, 1993).

Lipid oxidation of the lamb meat was not influenced by diet and stunning methods, and oxidative rancidity was not observed. Linares et al. (2007a) evaluated the effect of pre-slaughter management (stunning with electrical stimulation, $\mathrm{CO}_{2}$ gas and without stunning) on lipid oxidation (TBARS in units of $\mathrm{mg}$ malondialdehyde $/ \mathrm{kg}$ of meat) and obtained values above $3.44 \mathrm{mg} / \mathrm{kg}$ in the meat of lambs stunned by electrical stimulation. According to Juncher et al. (2003), stress is related 
to lipid oxidation in the muscle, and therefore, improper management of the animals during stunning can affect the rancidity levels in meat and meat products. However, this effect was not observed in the present study. Kennedy, Buckley and Kerry (2005) found TBARS values of $0.99 \mathrm{mg} /$ $\mathrm{kg}$ of meat.

Meat tenderness is an important factor in the meat sales business because most consumers seek tender meat and typically purchase based on past experience. In the present study, the tenderness values found were determined satisfactory because the evaluated meat samples were characterized as tender.

It can be observed in Table 5 that diets and stunning methods did not affect $(\mathrm{P}>0.05)$ the erythrocyte count, the hematocrit level or the concentrations of glucose, lactate and cortisol.

Table 5. Blood parameters of feedlot lambs.

\begin{tabular}{|c|c|c|c|c|c|c|c|}
\hline Parameter & $\begin{array}{c}\text { Total } \\
\text { leukocytes } \\
\times 10^{3} / \mu \mathrm{L} \\
\end{array}$ & $\begin{array}{c}\text { Erythrocytes } \\
\times 10^{6} / \mu \mathrm{L}\end{array}$ & $\begin{array}{c}\text { Hematocrit } \\
\%\end{array}$ & $\begin{array}{c}\text { Glucose } \\
\mathrm{mg} / \mathrm{dL}\end{array}$ & $\begin{array}{c}\text { Creatine } \\
\text { U/L }\end{array}$ & $\begin{array}{l}\text { Lactate } \\
\mathrm{mg} / \mathrm{dL}\end{array}$ & $\begin{array}{c}\text { Cortisol } \\
\text { ng/ml }\end{array}$ \\
\hline \multicolumn{8}{|l|}{ Diet } \\
\hline G0 & 5.17 & 14.60 & 42.62 & 75.83 & 70.53 & 8.83 & 3.15 \\
\hline G10 & 6.23 & 15.19 & 45.45 & 71.61 & 67.91 & 8.19 & 3.30 \\
\hline \multicolumn{8}{|l|}{ Method } \\
\hline Pistol & $4.70 \mathrm{~b}$ & 14.60 & 43.59 & 70.83 & $56.56 \mathrm{~b}$ & 7.97 & 3.36 \\
\hline Electrical stimulation & $7.22 \mathrm{a}$ & 15.19 & 44.48 & 76.61 & $81.89 \mathrm{a}$ & 9.05 & 3.10 \\
\hline Fonte de Variação & \multicolumn{7}{|c|}{ P-values } \\
\hline Dieta & 0.1221 & 0.2507 & 0.0587 & 0.1578 & 0.6433 & 0.6282 & 0.8492 \\
\hline Método & $<0.0001$ & 0.2444 & 0.5424 & 0.0554 & $<0.0001$ & 0.4179 & 0.7339 \\
\hline Dieta x Método & 0.893 & 0.4844 & 0.5202 & 0.6414 & 0.8594 & 0.1422 & 0.3952 \\
\hline CV (\%) & 37.17 & 10.64 & 10.43 & 12.53 & 25.62 & 49.24 & 74.84 \\
\hline
\end{tabular}

Means followed by different letters in the column, differ by Tukey testa $\mathrm{t} 5 \%$ probability

G0: control without glycerin; G10: formulated with $10 \%$ glycerin-

$\mathrm{CV}=$ coefficient of variation.

Source: Elaboration of the authors.

The erythrocyte count found in the present study was at the upper limit of the range (9 to 15 $\mathrm{x} 10^{6} / \mu \mathrm{L}$ ) suggested as normal for the species by Kaneko, Harvey and Bruss (2008), with an average of $14.90 \times 10^{6} / \mu \mathrm{L}$. Values above $15.00 \times 10^{6} \%$ $\mu \mathrm{L}$ can be considered as cases of polycythemia. Polycythemia is characterized by an absolute increase in red blood cells, which increases the hematocrit and expands the total blood volume (SOTO et al., 2008). This excessive concentration of hematocrit makes the mucous membranes appear redder and increases blood viscosity, which reduces blood flow. This effect most likely explains the low bleeding efficiency indicated by the brightness of the meat color 24 hours after slaughter. Peripheral vasoconstriction occurs in stressed animals because blood is directed to vital organs and muscles for a possible flight response (the sympathetic nerve activation; SNA), which increases blood pressure, stimulating hematopoietic organs to produce cells, among other reasons, and this may explanation the increase in erythrocytes because hemoglobin transports oxygen to the muscles.

Consequently, the hematocrit level was at the upper limit of the range (27 to $45 \%$ ) suggested by Kaneko, Harvey and Bruss (2008) because values 
above $45 \%$ are characteristic of dehydration. However, dehydration was not observed in the present study because the animals received water ad libitum until the time of slaughter.

The data on glucose concentrations obtained in the present experiment showed values within the range (50 to $80 \mathrm{mg} / \mathrm{dL}$ ) considered normal for sheep by Lopes, Biondo and Santos (2007). Similar values (average concentrations of $75.53 \mathrm{mg} / \mathrm{dL}$ ) were found by Miranda-de la Lama et al. (2010), who studied the influence of indicators of welfare on lamb meat quality. Gunn et al. (2010b) studied the effects of glycerol concentrations $(0,15,30$ and $45 \%$ ) on the blood parameters of lambs and found lower values than those observed in the present study, in which the average glucose concentrations were $72.2,66.5,60.2$ and $61.3 \mathrm{mg} / \mathrm{dL}$, respectively.

Glucose is a metabolite that represents the metabolic energy pathway. However, glucose is not highly sensitive to variations in dietary energy intake because the blood concentration of glucose is regulated by a hormonal mechanism designed to efficiently maintain constant concentrations of this blood parameter. Therefore, the energy deficit must be severe to decrease blood glucose concentration (GONZÁLEZ et al., 2000), which indicates that the energy supply of the diets was satisfactory for the animals because the concentration of glucose is an important tool to assess the energy status of the animals.

The electrically stunned animals had a higher concentration of total leukocytes $\left(7.22 \times 10^{3} / \mu \mathrm{L}\right)$ than the animals stunned with a non-penetrating bolt pistol $\left(4.70 \times 10^{3} / \mu \mathrm{L}\right)$. Although the total leukocyte counts differed, the difference was within the reference range ( 4 to $12 \times 10^{3} / \mu \mathrm{L}$ ) suggested by Kaneko, Harvey and Bruss (2008) as normal for the ovine species. Miranda-de la Lama et al. (2010) found a similar value of $6.83 \times 10^{3} / \mu \mathrm{L}$ when these researchers studied the influence of welfare indicators on lamb meat quality.

Creatine kinase is a highly sensitive and stable muscle-specific enzyme associated with myopathy (SHPIGEL; AVIDAR; BOGIN, 2003). Increased blood concentration of this enzyme is used to diagnose nutritional muscular dystrophy. As shown in Table 5, there was no significant difference between lambs as a result of diet. The mean serum concentration was $69.22 \mathrm{U} / \mathrm{L}$, which is considered above the range of normal values $(0-40 \mathrm{U} / \mathrm{L})$ suggested by Lopes, Biondo and Santos (2007). The average blood concentration of creatine kinase in electrically stunned lambs was higher (81.89 $\mathrm{U} / \mathrm{L})$ than that of lambs stunned by non-penetrating bolt pistol (56.56 U/L). It is likely that signs of poor stunning, such as eye movements, contraction of the front limbs and rhythmic breathing, observed after electrical stunning with consequent muscular effort related to the return to consciousness after stunning contributed to the elevation of concentrations.

Although there was no significant difference in lactate concentrations, the mean concentrations were close to the normal range of 9-12 mg/dL (LOPES; BIONDO; SANTOS, 2007). Although not observed in the present study, increased lactate levels can be caused by intense stress because under intense stress, muscle exhaustion can occur. Muscle exhaustion generates a large quantity of lactic acid, which can be released into the bloodstream. Additionally, the release of corticosteroids and catecholamine can occur as a result of fear or excitement, which can also cause rapid glycogenolysis and excess lactate (Bertoloni et al., 2006).

The cortisol concentrations found in the present study were well below the normal level of $22.4 \mathrm{ng} /$ $\mathrm{ml}$ mentioned by Kaneko, Harvey and Bruss (2008). In addition, the mean cortisol levels were below the mean value of $29.2 \mathrm{ng} / \mathrm{ml}$ reported by Linares, Bórnez and Vergara (2008), who measured this hormone in lambs stunned by electrical stimulation and carbon dioxide.

The results show the efficiency of the stunning methods adopted. Even when changes occurred that indicated stress during the pre-slaughter 
management, this stress was not severe enough to damage the meat. Notably, the indicators of evaluated meat quality showed good results. DFD and PSE meat were not indicated because a normal decrease in $\mathrm{pH}$ values was found.

On 11 May 2012, the Federal Council of Veterinary Medicine (Conselho Federal de Medicina Veterinária - CFMV) supported the results of this research by issuing Resolution $\mathrm{n}^{\circ} 1000$. This resolution presented procedures and methods of euthanasia and other measures and determined that the accepted method to stun ruminants was a bolt pistol followed by bleeding. Thus electrical stunning was eliminated, which was a practice commonly used to slaughter sheep in Brazil.

The non-penetrating bolt pistol can be considered as an alternative method for stunning lambs based on welfare and meat quality considerations. The bolt pistol showed advantages in the clarity of meat color 24 hours after slaughter and with respect to the concentrations of total leukocytes and creatine kinase and in particularly with respect to indicators of stunning efficiency.

All procedures involving animals during the study were approved by the Ethics Committee on Animal Use before the initiation of research.

\section{Acknowledgements}

The Fundação de Amparo à Pesquisa do Estado de São Paulo.

The Caramuru Alimentos Ltda.

\section{References}

ABO EL-NORB, S.; ABUGHAZALEHA, A. A.; POTUA, R. B. Effects of differing levels of glycerol on rumen fermentation and Bacteria. Animal Feed Science and Technology, Amsterdam, v. 162, n. 1, p. 99-105, 2010.

BERTOLONI, W.; SILVEIRA, E. T. F.; LUDTKE, C. B.; ANDRADE, J. C. Avaliação de diferentes híbridos suínos submetidos à insensibilização elétrica e gasosa
$\left(\mathrm{CO}_{2}\right)$. Parte 1 - mensuração de indicadores sanguíneos e estresse. Ciência e Tecnologia de Alimentos, Campinas, v. 26, n. 3, p. 564-570, 2006.

CAÑEQUE, V.; SAÑUDO, C. Estandarización de las metodologias para evaluar la calidad del producto (animal vivo, canal, carne y grasa em los rumiantes. Madrid: Instituto Nacional de Investigación y Tecnologia Agrária y Alimentaria, 2005. 448 p.

CEZAR, M. F.; SOUSA, W. H. Carcaças ovinas e caprinas: obtenção, avaliação e classificação. Uberaba: Agropecuária Tropical, 2007. $232 \mathrm{p}$.

CHANNON, H. A.; PAYNE, A. M.; WARNER, R. D. Effect of stun duration and current level applied during head to back and head only electrical stunning of pigs on pork quality compared with pigs stunned with $\mathrm{CO}_{2}$. Meat Science, Barking, v. 65, n. 4, p. 1325-1333, 2003.

CHUNG, Y. H.; RICO, D. E.; MARTINEZ, C. M. Effects of feeding dry glycerin to early postpartum Holstein dairy cows on lactational performance and metabolic profiles. Journal of Dairy Science, Madison, v. 90, n. 12, p. 56825691, 2007.

CROSS, H. R.; WEST, R. L.; DUTSON, T. R. Comparison of methods for measuring sarcomere length in beef semitendinosus muscle. Meat Science, Barking, v. 5, n. 4, p. 261-266, 1981.

DE BOEVER, J. L.; COTTYN, B. G.; DEBRADANGER, D. L. Equations to predict digestibility and energy value of grass silages, maize silages, grass hays, compound feeds and raw materials for cattle. Nutrition Abstracts and Reviews, Series B, v. 69, n. 11, p. 835-850, 1999.

DEFRAIN, J. M.; HIPPEN, A. R.; KALSCHEUR, K. F. Feeding glycerol to transition dairy cows: Effects on blood metabolites and lactation performance. Journal of Dairy Science, Madison, v. 87, n. 12, p. 4195-4206, 2004.

EKIZ, B.; EKIZ, E. E.; KOCAK, O.; YALCINTHAN, H.; YILMAZ, A. Effect of pre-slaughter management regarding transportation and time in lairage on certain stress parameters, carcass and meat quality characteristics in Kivircik lambs. Meat Science, Barking, v. 90, n. 4, p. 967-976, 2012.

FOURY, A.; DEVILLERS, N.; SANCHEZ, M. P.; GRIFFON, H.; LE ROY, P.; MORMEDE, P. Stress hormones, carcass composition and meat quality in Large White x Duroc pigs. Meat Science, Barking, v. 69, n. 2, p. 705-707, 2005.

GOMES, M. A. B.; MORAES, G. V.; MATAVELI, M.; MACEDO, F. A. F.; CARNEIRO, T. C.; ROSSI, R. M. Performance and carcass characteristics of lambs fed on diets supplemented with glycerin from biodiesel 
production. Revista Brasileira de Zootecnia, Viçosa, MG, v. 40, n. 10, p. 2211-2219, 2011.

GUNN, P. J.; NEARY, M. K.; LEMENAGER, R. P.; LAKE, S. L. Effects of crude glycerin on performance and carcass characteristics of finishing wether lambs. Journal of Animal Science, Champaign, v. 88, n. 5, p. 1771-1776, 2010a.

GUNN, P. J.; SCHULTZ, A. F.; VAN EMON, M. L.; NEARY, M. K.; LEMENAGER, R. P.; RUSK, C. P.; LAKE, S. L. Effects of elevated crude glycerin concentrations on feedlot performance, carcass characteristics, and serum metabolite and hormone concentrations in finishing ewe and wether lambs. The Professional Animal Scientist, Champaign, v. 26, n. 3, p. 298-306, 2010b.

GONZÁLEZ, F. H. D.; BARCELLOS, J. O.; OSPINA, H.; RIBEIRO, L. A. O. Perfil metabólico em ruminantes: seu uso em nutrição e doenças nutricionais. Porto Alegre: Gráfica UFRGS, 2000. 106 p.

HAMBRECHT, E.; EISSEN, J. J.; NOOIJEN, R. I. J.; DUCRO, B. J.; SMITS, C. H. M.; den HARTOG, L. A.; VERSTEGEN, M. W. A. Pre-slaughter stress and muscle energy largely determine pork quality at two commercial processing plants. Journal of Animal Science, Champaign, v. 82, n. 5, p. 1401-1409, 2004.

INTERNATIONAL COMMITTEE ON ILLUMINATION - CIE. Joint ISO/CIE Standard. Part 4:1976 L*a*b* Colour Space ISO 11664-4:2008(E)/ CIE S 014 -4/E, 2007.

JUNCHER, D.; RONN, B.; HANSEN, T. B.; HENCKEL, P.; KARLSSON, A.; SKIBSTED, L. H. Effect of preslaughter physiological conditions on the oxidative stability of colour and lipid during chill storage of sliced, retail packed roast ham. Meat Science, Barking, v. 63, n. 2, p. 151-159, 2003.

KANEKO, J. J.; HARVEY, J. W.; BRUSS, M. L. Clinical biochemistry of domestic animals. 6. ed. San Diego: Academic Press, 2008. 928 p.

KENNEDY, C.; BUCKLEY, D. J.; KERRY, J. P. Influence of different gas compositions on the short-term storage stability of mother packaged retail-ready lamb packs. Meat Science, Barking, v. 69, n. 1, p. 27-33, 2005.

LAGE, J. F.; PAUlinO, P. V. R.; PEREIRA, L. G. R.; VALADARES FILHO, S. C.; OLIVEIRA, A. S.; DETMANN, E.; SOUZA, N. A. P.; LIMA, J. C. M. Glicerina bruta na dieta de cordeiros terminados em confinamento. Pesquisa Agropecuária Brasileira, Brasília, v. 45, n. 9, p. 1012-1020, 2010.

LINARES, M. B.; BERRUGA, M. I.; BÓRNEZ, R.; VERGARA, H. Lipid oxidation in Lamb meat: effect of the weight, handling previous slaughter and modified atmospheres. Meat Science, Barking, v. 76, n. 4, p. 715$729,2007 \mathrm{a}$.

LINARES, M. B.; BÓRNEZ, R.; VERGARA, H. Cortisol and catecolamine levels in lambs: effects of slaughter weight and type of stunning. Livestock Science, Denmark, v. 115, n. 1, p. 53-61, 2008.

Effect of different stunning systems on meat quality of light Lamb. Meat Science, Barking, v. 76, n. 4, p. 675-681, 2007b.

LOPES, S. T. A.; BIONDO, A. W.; SANTOS, A. P. Manual de patologia clínica veterinária. 3. ed. Santa Maria: UFSM/CCR, 2007. 117 p.

MACH, N.; BACH, A.; VELARDE, A. Association between animal, transportation, slaughterhouse practices, and meat $\mathrm{pH}$ in beef. Meat Science, Barking, v. 78, n. 3, p. 232-238, 2008.

MILTENBURG, G. A. J.; WENSING, T. H.; SMULDERS, F. J. M.; BREUKINK, H. J. Relationship between blood hemoglobin, plasma and tissue iron, muscle heme pigment, and carcass color of veal. Journal of Animal Science, Champaign, v. 70, n. 9, p. 2766-2772, 1992.

MIRANDA-de la LAMA, G. C.; RIVERO,L.; CHACÓN, G.; GARCIA-BELENGUER, S.; VILLARROEL, M.; MARIA, G. A. Effects of the pre-slaughter logistic chain on some indicators of welfare in lambs. Livestock Science, Denmark, v. 128, n. 1, p. 52-59, 2010.

MIRANDA-de la LAMA, G. C.; VILARROEL, M.; OLLETA, J. L.; ALIERTA, S.; SAÑUDO, C.; MARIA, G. A. Effect of the pre-slaughter logistic chain on meat quality of lambs. Meat Science, Barking, v. 83, n. 4, p. 604-609, 2009.

NATIONAL RESEARCH COUNCIL - NRC. Nutrient requirements of small ruminants. Washington: National Academy, 2007. 362 p.

ÖNENÇ, A.; KAYA, A. The effects of electrical stunning and percussive captive bolt stunning on meat quality of cattle processed by Turkish slaughter procedures. Meat Science, Barking, v. 66, n. 4, p. 809-815, 2004.

PARKER, A. J.; DOBSON, G. P.; FITZPATRICK, L. A. Physiological and metabolic effects of prophylactic treatment with the osmolytes glycerol and betaine on Bos indicus steers during long duration transportation. Journal of Animal Science, Champaign, v. 85, n. 11, p. 653-657, 2007.

PARSONS, G. L.; SHELOR, M. K.; DROUILLARD, J. S. Performance and carcass traits of finishing heifers fed crude glycerin. Journal of Animal Science, Champaign, v. 87, n. 2, p. 653-657, 2009. 
PIKUL, J.; LESZCZYNSKI, D. E.; KUMMEROW, F. A. Evaluation of three modified TBA methods for measuring lipid oxidation in chicken meat. Journal of Agricultural of Food Chemistry, California, v. 37, n. 5, p. 1309-1313, 1989.

POL, A.; DEMEYER, D. I. Fermentation of methanol in the sheep rumen. Applied and Environmental Microbiology, Washington D.C, v. 54, n. 3, p. 832-834, 1988.

PURCHAS, R. W.; AUNGSUPAKORN, R. Further investigations into the relationship between ultimate $\mathrm{pH}$ and tenderness of meat from bulls and steers. Meat Science, Barking, v. 34, n. 2, p. 163-178, 1993.

PYATT, A.; DOANE, P. H.; CECAVA, M. J. Effect of crude glycerin in finishing cattle diets. Journal of Animal Science, Champaign, v. 85, p. 412, 2007. Supplement 1.

RESTLE, J.; NEUMANN, M.; ALVES FILHO, D. C.; PASCOAL, L. L.; ROSA, J. R. P.; MENEZES, L. F. G. de; PELLEGRINI, L. G. de. Terminação em confinamento de vacas e novilhas sob dietas com ou sem monensina sódica. Revista Brasileira de Zootecnia, Viçosa, MG, v. 30, n. 6, p. 1801-1812, 2001.

SAÑUDO, C.; ENSER, M. E.; CAMPO, M. M.; NUTE, G. R.; MARÍA, G.; SIERRA, I. E.; WOOD, J. D. Fatty acid composition and sensory characteristics of lamb carcasses from Britain and Spain. Meat Science, Barking, v. 54, n. 4, p. 339-346, 2000.

STATISTICAL ANALYSIS SYSTEM INSTITUTE SAS Institute Inc. SAS/STAT. Cary: Technical Report, 2001. Release 8.2.

SCHRÖDER, A.; SÜDEKUM, K. H. Glycerol as a byproduct of biodiesel production in diets of ruminants. Kiel: University of Kiel, 2007. Available at: <http:// regional.org.au/au/gcirc/1/241.htm>. Accessed on: 18 mar. 2009.

SHPIGEL, N. Y.; AVIDAR, Y.; BOGIN, E. Value of measurements of the serum activities of creatine phosphokinase, aspartate aminotransferase and lactate dehydrogenase for predicting whether recumbent dairy cows will recover. Veterinary Record, London, v. 152, n. 25, p. 773-776, 2003.

SILVA SOBRINHO, A. G.; PURCHAS, R. W.; KADIM, I. T. Características de qualidade da carne de ovinos de diferentes genótipos e idades ao abate. Revista Brasileira de Zootecnia, Viçosa, MG, v. 34, n. 3, p. 1070-1078, 2005.

SNIFFEN, C. J.; BEVERLY, R. W.; MOONEY, C. S.; ROE, M. B.; SKIDMORE, A. L. Nutrient requirement versus supply in dairy cow: strategies to account for variability. Journal of Dairy Science, Madison, v. 76, n. 10, p. 3160-3178, 1993.

SOTO, J. C. H.; OLIVEIRA, R. G. de; MENEGUETI, V. C.; SACCO, S. R. Policitemia e eritrócitos em animais domésticos. Revisão de Literatura. Revista Científica Eletrônica de Medicina Veterinária, Garça, n. 11, ano VI, 2008.

THORNTON, H. Compêndio de inspeção de carnes. Londres: Bailliere Tindall an Cassel, 1969. 665 p.

TROEGER, K.; WOLTERSDORF, W. Electrical stunning and meat quality in the pig. Fleischwirtschaft, Frankfurt, v. 70, n. 8, p. 901-904, 1990.

VERGARA, H.; GALLEGO, L. Effect of electrical stunning on meat quality of lamb. Meat Science, Barking, v. 56, n. 4 , p. $345-349,2000$.

VERGARA, H.; LINARES, M. B.; BERRUGA, M. I.; GALLEGO, L. Meat quality in suckling lambs: effects of pré-slaughter handling. Meat Science, Barking, v. 69, n. 3, p. 473-478, 2005.

VIEIRA, T. R. L.; CUNHA, M. G. G.; GARRUTTI, D. S.; DUARTE, T. F.; FÉLEX, S. S. S.; PEREIRA FILHO, J. M.; MADRUGA, M. S. Propriedades físicas e sensoriais da carne de cordeiros Santa Inês terminados em dietas com diferentes níveis de caroço de algodão integral (Gossypium hirsutum). Ciência e Tecnologia de Alimentos, Campinas, v. 30, n. 2, p. 372-377, 2010. 